\title{
Synergetic Co-Production of Beer Colouring Agent and Solid Fuel from Brewers' Spent Grain in the Circular Economy Perspective
}

\author{
Mateusz Jackowski ${ }^{1, *(0)}$, Łukasz Niedźwiecki ${ }^{2}, *\left(\mathbb{D}\right.$, Krzysztof Mościcki $^{2}\left(D\right.$, Amit Arora ${ }^{3}$, Muhammad Azam Saeed ${ }^{4}$, \\ Krystian Krochmalny ${ }^{2}$, Jakub Pawliczek ${ }^{2}$, Anna Trusek ${ }^{1}{ }^{1}$, Magdalena Lech ${ }^{1}$, Jan Skřínský ${ }^{5}{ }^{1}$, Jakub Čespiva ${ }^{5}$, \\ Ján Vereš ${ }^{5}$, Tadeáš Ochodek ${ }^{5}$ and Halina Pawlak-Kruczek ${ }^{2}$
}

check for updates

Citation: Jackowski, M.;

Niedźwiecki, Ł.; Mościcki, K.; Arora, A.; Saeed, M.A.; Krochmalny, K.; Pawliczek, J.; Trusek, A.; Lech, M.; Skřínský, J.; et al. Synergetic Co-Production of Beer Colouring Agent and Solid Fuel from Brewers Spent Grain in the Circular Economy Perspective. Sustainability 2021, 13, 10480. https://doi.org/10.3390/ su131810480

Academic Editors: Tiziana Amoriello and Roberto Ciccoritti

Received: 30 August 2021

Accepted: 13 September 2021

Published: 21 September 2021

Publisher's Note: MDPI stays neutral with regard to jurisdictional claims in published maps and institutional affiliations.

Copyright: (c) 2021 by the authors. Licensee MDPI, Basel, Switzerland. This article is an open access article distributed under the terms and conditions of the Creative Commons Attribution (CC BY) license (https:// creativecommons.org/licenses/by/ $4.0 /)$.
1 Department of Micro, Nano and Bioprocess Engineering, Faculty of Chemistry, Wroclaw University of Science and Technology, 50-373 Wroclaw, Poland; anna.trusek@pwr.edu.pl (A.T.); magdalena.lech@pwr.edu.pl (M.L.)

2 Department of Energy Conversion Engineering, Faculty of Mechanical and Power Engineering, Wrocław University of Science and Technology, 50-370 Wroclaw, Poland; krzysztof.moscicki@pwr.edu.pl (K.M.); krystian.krochmalny@pwr.edu.pl (K.K.); 228714@student.pwr.edu.pl (J.P.); halina.pawlak@pwr.edu.pl (H.P.-K.)

3 Department of Chemical Engineering, Shaheed Bhagat Singh State University, Punjab, Ferozepur 152004, India; amitarora@sbsstc.ac.in

4 Department of Chemical Engineering, University of Engineering and Technology, Lahore 39161, Pakistan; azam.saeed@uet.edu.pk

5 VŠB-Energy Research Center, Technical University of Ostrava, 70800 Ostrava, Czech Republic; jan.skrinsky@vsb.cz (J.S.); jakub.cespiva@vsb.cz (J.Č.); jan.veres@vsb.cz (J.V.); tadeas.ochodek@vsb.cz (T.O.)

* Correspondence: mateusz.jackowski@pwr.edu.pl (M.J.); lukasz.niedzwiecki@pwr.edu.pl (Ł.N.)

Abstract: Brewers' Spent Grain is a by-product of the brewing process, with potential applications for energy purposes. This paper presents the results of an investigation aiming at valorization of this residue by torrefaction, making product for two purposes: a solid fuel that could be used for generation of heat for the brewery and a colouring agent that could replace colouring malt for the production of dark beers. Decreased consumption of malt for such purposes would have a positive influence on the sustainability of brewing. Torrefaction was performed at temperatures ranging between $180{ }^{\circ} \mathrm{C}$ and $300^{\circ} \mathrm{C}$, with a residence time between 20 and $60 \mathrm{~min}$. For the most severe torrefaction conditions $\left(300^{\circ} \mathrm{C}, 60 \mathrm{~min}\right)$, the higher heating value of torrefied $\mathrm{BSG}$ reached $25 \mathrm{MJ} / \mathrm{kg}$. However, the best beer colouring properties were achieved for mild torrefaction conditions, i.e., $180^{\circ} \mathrm{C}$ for $60 \mathrm{~min}$ and $210^{\circ} \mathrm{C}$ for $40 \mathrm{~min}$, reaching European Brewery Convention colours of 145 and 159, respectively. From the solid fuel properties perspective, the improvements offered by torrefaction in such mild conditions were modest. Overall, the obtained results suggest some trade-off between the optimum colouring properties and optimum solid fuel properties that need to be considered when such dual-purpose torrefaction of BSG for brewery purposes is implemented.

Keywords: torrefaction; brewers' spent grain; sustainable brewing; circular economy; beer

\section{Introduction}

Beer has been known to humanity for millennia. The first evidence of brewing was found in the Neolithic period, and the first industrial-scale breweries were discovered in ancient Egypt [1,2]. Today, it is one of the most popular drinks in the world. Numerous types of beer exist that vary in colour, alcohol content, used hops, and yeasts. Those properties have their origin in the production process.

Beer colour may be obtained in two ways. The first is to add roasted malt during mashing. Dark malt is produced in the malthouse from standard malt grains by roasting. Such malt is biologically inactive and does not contribute to enzyme activity during mashing. Another approach to making beer darker is to use dark malt extracts added during wort boiling [3-5]. 
Brewers' Spent Grain (BSG) is a residue left after lautering. BSG has been considered as a feedstock for many different processes [6,7]. There are various novel, sustainable ways of using BSG, including using it as an additive to sausages [8] or bakery products [9-11], extraction of anti-oxidants [12,13], including polyphenols [14,15], extraction of proteins [16], functional cardioprotective lipids [17], material for disposable trays [18], natural rubber modifier [19], fodder for edible insects [20], as well as feedstock for production of pigments [21] and biochar, for subsequent use as soil amendment [22] or sustainable material for electrodes [23].

Biomass is nowadays deemed an energy source with utmost importance from the point of view of energy transition towards sustainable energy supply [24-27]. Worldwide production of BSG has been estimated as approximately 38.6 million tons [28]. BSG can be considered as a type of biomass, and its potential use as fuel has been suggested by several authors to date [29-31]. As novel valorization routes for waste-to-energy are deemed promising by many [32], some authors have suggested the use of hydrothermal carbonization (HTC) as a suitable valorization process, allowing improvement of fuel parameters, with respect to unprocessed BSG, i.e., an increase in the higher heating value (HHV) and reduction of ash content [33]. Analysis of the composition of the effluent from HTC of BSG, performed by Jackowski et al. [34], using gas chromatography coupled with mass spectrometry (GC-MS), suggested its utilization in the anaerobic digestion process [34]. Poerschmann et al. concluded that hydrochars produced from BSG could be suitable for soil-improvement applications [35]. Pyrolysis GC-MS (Py-GC-MS) analysis of BSG and corresponding hydrochars was performed by Olszewski et al. [36], reporting fewer $\mathrm{N}$ compounds for pyrolysis of hydrochars performed at relatively low temperatures compared to pyrolysis of raw BSG [36]. The Maillard reaction, occurring during hydrothermal carbonization of BSG, was suspected to be the reason behind such results [36]. Ferreira et al. suggested using BSG as a feedstock for steam gasification and obtained good quality gas with a heating value ranging between 8.1 and $9.0 \mathrm{MJ} / \mathrm{m}^{3} \mathrm{~N}$, reaching concentrations of hydrogen between $22.8 \%$ and $30.2 \%$ [37]. Dudek et al. investigated two alternative waste-to-energy and waste-to-carbon routes for BSG, one using BSG as anaerobic digestion substrate and another utilizing torrefaction of BSG to produce an additive enhancing anaerobic digestion, concluding that synergy could be obtained when using these routes in parallel [38]. The study also highlighted the potential role of Maillard reaction products, which form during torrefaction of BSG [38]. Products of Maillard reactions could prove useful for use as colouring agents [39], which is very important from the point of view of the sensory analysis of beers [40]. Currently, roasting of malt is the most commonly used method. The use of residues, such as spent grain, for this purpose, is tempting from the point of view of circular economy principles.

Little information is available in the literature on the torrefaction of BSG to improve its fuel properties. The torrefaction process is used for thermal valorization of solid fuels, thus improving their properties, and in consequence, promoting sustainability in the energy generation sector [41-43]. Torrefaction is sometimes called slow pyrolysis, and it typically takes place at temperatures between $250^{\circ} \mathrm{C}$ and $300{ }^{\circ} \mathrm{C}$ [44-47], with residence times ranging between 10 and $60 \mathrm{~min}$ [48-51]. Torrefied biomass can be an attractive fuel for the power industry for combustion and co-firing [52-55], mainly due to increased grindability [56,57], which extends the time between renovations of the mill [58], and energy density [59-62]. In addition, reduction of moisture content could be beneficial in many energy conversion processes $[45,63,64]$. Moreover, the advantages mentioned above are beneficial from the point of view of fuel logistics and storage $[65,66]$. Furthermore, torrefaction typically decreases oxygen content and increases the carbon content of the valorized fuel [53,67-71]. This enhancement could be deemed beneficial from the point of view of pyrolysis [72-75] or gasification [76-79]. Regarding reactivity of the torrefied material, Huescar Medina et al. [80] observed that torrefaction slightly increased the reactivity of torrefied spruce wood in terms of $\mathrm{K}_{\mathrm{St}}$ (deflagration index), $\mathrm{P}_{\max }$ (maximum explosion pressure), and flame speed, whereas Jian et al. observed reduced char reactivity 
at elevated pyrolysis temperatures [81]. Such behaviour contributed to significant crosslinking and poly-condensation in severe torrefaction conditions, eliminating the active sites and thus reducing the conversion and reactivity of char during pyrolysis [81].

Torrefaction of BSG could potentially enhance its fuel properties, thus making it more suitable for energy purposes. However, it seems plausible to hypothesize that torrefaction of BSG could be used to produce a colouring agent, which could replace roasted malt. This could offer important benefits through the effect of synergy, as one installation could be used to turn residue of beer production into brewing substrate, and at the same time, supply a brewery with its own fuel. This, in turn, could prove beneficial in supplying the energy needs of a brewery from renewable energy source (biomass) and facilitating practical implementation of the circular economy rules by reusing residues for production processes.

Therefore, the goal of this interdisciplinary paper is the experimental validation of such an approach by assessing improvements of the fuel properties of torrefied BSG and determination of the suitability of using torrefied BSG as a beer colouring agent with the additional determination of possible influence on taste through sensory analyses.

\section{Materials and Methods}

Since the beer production process could significantly influence the properties of the corresponding BSG [82], the beer production process was performed in a controlled manner in a pilot-scale brewery and characterization of the main product of brewing (beer) is also an intrinsic part of this investigation. The residual BSG for further tests was produced in a pilot-scale brewing installation at the Wrocław University of Science and Technology. This pilot scale unit can be used for brewing approximately $1 \mathrm{hL}$ of beer, with full control over each unit operation of the process (Figure 1).

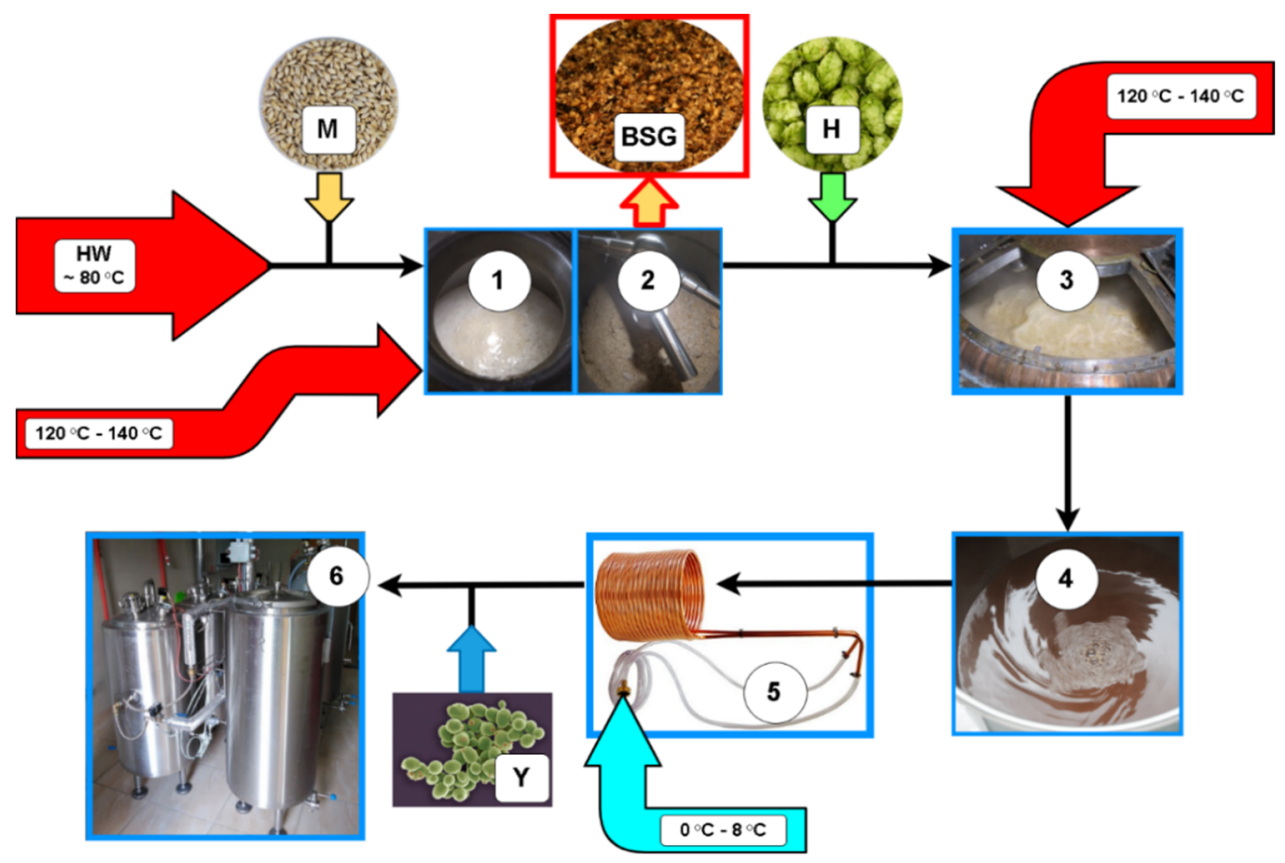

Figure 1. Pilot-scale installation diagram, with special emphasis on unit operations with heat/cold demand. Heat supply marked with red arrows, cold supply marked with a cyann arrow (1-mashing; 2-lautering; 3-boiling; 4-wort separation in a whirlpool; 5-wort cooling; 6-fermentation; M-malt; BSG—Brewers' Spent Grain; H—hops; Y—yeasts).

Overall, this installation works in the same manner as industrial breweries, including controlling the process and technical solutions. Obtained brewers' spent grains were a by-product of standard pilsner beer production. For brewing, $20 \mathrm{~kg}$ of pilsner malt and $100 \mathrm{~L}$ of water were used. The mashing regime was as follows: $65^{\circ} \mathrm{C}$ for $30 \mathrm{~min}, 72{ }^{\circ} \mathrm{C}$ for $20 \mathrm{~min}, 78^{\circ} \mathrm{C}$ for $10 \mathrm{~min}$. The mixture was transferred into a lauter tun in the next 
step, filtrated and sparged with $10 \mathrm{~L}$ of hot water. Through the filtration, $98 \mathrm{~L}$ of wort and approximately $10 \mathrm{~kg}$ of brewers' spent grains dry mass were achieved. Wort extract was 11.5 Brix. In the next step, the wort was hopped, and yeasts were added in order to produce standard pilsner beer.

All samples of BSG and reference materials (raw BSG, barley, pilsner malt and dark malt) were mashed according to the congress mash technique (European Brewery Convention 4.5.1). Raw materials $(50 \mathrm{~g})$ were ground and mixed with $200 \mathrm{~mL}$ of distilled water in temperature $45^{\circ} \mathrm{C}$. The temperature was held for $30 \mathrm{~min}$ and mash was stirred at $90 \mathrm{rpm}$. The temperature was then raised up to $70^{\circ} \mathrm{C}$ and held for $10 \mathrm{~min}$. After that step, $100 \mathrm{~mL}$ of distilled water at a temperature of $70^{\circ} \mathrm{C}$ was added and temperature was held for another $15 \mathrm{~min}$. Finally, wort was cooled down to $25^{\circ} \mathrm{C}$ and filled to $450 \mathrm{~mL}$ with distilled water. Before analysis, samples were centrifugated at $3000 \mathrm{rpm}$ for $3 \mathrm{~min}$ in order to remove turbidity. Wort extract was determined using a refractometer scaled in Brix (Bx) degrees. Wort colour was obtained using spectrophotometer Hitachi U-1900 and a 1 -cm-length quartz cuvette. Absorbance was measured in a wavelength of $430 \mathrm{~nm}$. The results were calculated to the units of European Brewery Convention (EBC) scale using following equation:

$$
E B C=A_{430} \cdot f \cdot 25
$$

where

$A_{430}$-absorbance in wavelength $430 \mathrm{~nm}$

$f$-dilution factor

Aroma profiles were determined in an organoleptic manner by two researchers. Only aromas felt distinctly by both were taken into consideration. Compounds responsible for aroma are mostly created in Maillard reactions. Among them there are compounds whose aroma is described as acrid, toffee, coffee, roasted, nutty, bread, caramel [3].

Torrefaction was performed in stainless steel Petri dishes, each with a diameter of $120 \mathrm{~mm}$ and a height of $20 \mathrm{~mm}$. Each was filled with dried BSG. The BSG was dropped freely into each dish from a height of approximately $10 \mathrm{~cm}$ until the container was overfilled and a cone was formed. Subsequently, a straight ruler was used to scantle the excess BSG. The mass of empty and full dish was checked for each sample using Radwag AS 310/C/2 scale with $0.1 \mathrm{mg}$ resolution. The bulk density of the spent grain was determined to be $246 \mathrm{~kg} / \mathrm{m}^{3}$. The dishes were subsequently closed with stainless steel lids to prevent air from accessing the material during torrefaction (apart from the air left in the interstitial space). Torrefaction was performed in a laboratory oven with a controlled temperature and connected ventilation. In each case, the oven was heated up to the selected temperature. The closed dishes were placed in the hot oven, which were subsequently closed. After a prescribed time of the experiment, the closed dish was taken out of the oven and placed in a desiccator for cooling. The mass was subsequently checked for cooled torrefied samples, followed by the characterization of torrefied material from the point of view of its use as a fuel and as a colouring agent.

The performance of the torrefaction process is typically determined directly using mass yield $\left(Y_{m}\right)$ and energy yield $\left(Y_{e}\right)$ [83-86]. The indirect method was proposed by Weber et al. for simple assessment of performance of thermal biomass valorisation processes, such as production of biochar [87]. The use of an indirect method for performance assessment of the future industrial-scale installations is tempting, as in many cases, direct online measurement of mass and moisture content of the product could be problematic.

A method proposed by Weber et al. [87] is described by following equation:

$$
Y_{m \text { Weber }}=\frac{1-V M_{\text {feedstock }}}{1-V M_{\text {product }}}
$$

where

$Y_{m}$-mass yield (next part of the subscript indicating a method), -. 
$V M$-respective volatile matter content of feedstock and product, $\%$ dry

Moreover, the mass yield was also assessed indirectly, using ash tracer method [88]:

$$
Y_{m \text { ash tracer }}=\frac{A_{\text {feedstock }}}{A_{\text {product }}}
$$

where

$Y_{m}$-mass yield (next part of the subscript indicating a method), - .

$A$-respective ash content of feedstock and product, dry basis, $\% \mathrm{db}$

Additionally, the mass yield was determined using the direct method:

$$
Y_{m \text { direct }}=\frac{m_{\text {dry product }}}{m_{\text {dry feedstock }}}
$$

where

$Y_{m}$-mass yield (next part of the subscript indicating a method), -.

$m$-respective dry mass of feedstock and product, $\mathrm{kg}_{\mathrm{dry}}$

A well established formula was used for the calculation of the energy yield $[89,90]$ :

$$
Y_{e}=Y_{m} \cdot \frac{H H V_{\text {product }}}{H H V_{\text {feedstock }}}
$$

where

$Y_{e}$ - energy yield, -. $\mathrm{HHV}$ —respective higher heating value of feedstock and product, $\mathrm{MJ} / \mathrm{kg}$.

Ash content was determined according to a procedure described in EN 18122 [91]. The combustion was performed at $550{ }^{\circ} \mathrm{C}$, using porcelain dishes. Volatile matter content was determined according to EN 15148 [92]. The furnace was heated up to $900{ }^{\circ} \mathrm{C}$. The samples were subsequently inserted into the furnace and kept for $7 \mathrm{~min}$. The ultimate analysis was performed according to EN ISO 16948 using a Perkin Elmer 2400 analyzer [93]. Channiwala and Parikh [94]'s Equation (6) was used to estimate the HHV of both BSG and corresponding hydrochars:

$$
\mathrm{HHV}=0.3491 \cdot \mathrm{C}+1.1783 \cdot \mathrm{H}+0.1005 \cdot \mathrm{S}-0.1034 \cdot \mathrm{O}-0.0151 \cdot \mathrm{N}-0.0211 \cdot \mathrm{A}, \frac{\mathrm{MJ}}{\mathrm{kg}}
$$

where $\mathrm{C}, \mathrm{H}, \mathrm{O}, \mathrm{N}, \mathrm{S}$ and $\mathrm{A}$ represent carbon, hydrogen, oxygen, nitrogen, sulphur and ash contents of material, respectively, expressed in mass percentages on dry basis. An absolute error limit of $1.45 \%$ was confirmed for Equation (6), when concentrations were within specified limits of C $(0.00 \%-92.25 \%), \mathrm{H}(0.43 \%-25.15 \%), \mathrm{O}(0.00 \%-50.00 \%), \mathrm{N}$ $(0.00 \%-5.60 \%)$, S (0.00\%-94.08\%) and Ash (0.00\%-71.4\%) [94].

\section{Results and Discussion}

\subsection{Characterization of the Torrefaction Process}

Torrefaction of the BSG, performed within this study's scope, leads to the loss of dry mass of the material, which is typical for the process [95-99]. Mass yield depended on both the temperature of the process as well as residence time (Figure 2). Looking at the mass yield result (see Figure 2), it could be stated that very little effect could be observed at $180^{\circ} \mathrm{C}$. A similar observation was reported by Hejna et al. [34], who investigated a thermo-mechanical treatment of BSG with a maximum temperature of $180^{\circ} \mathrm{C}$. The study concluded that the loss of mass could primarily be attributed to loss of moisture and only to a limited extent to thermo-chemical influence, mostly Maillard reaction [100]. 


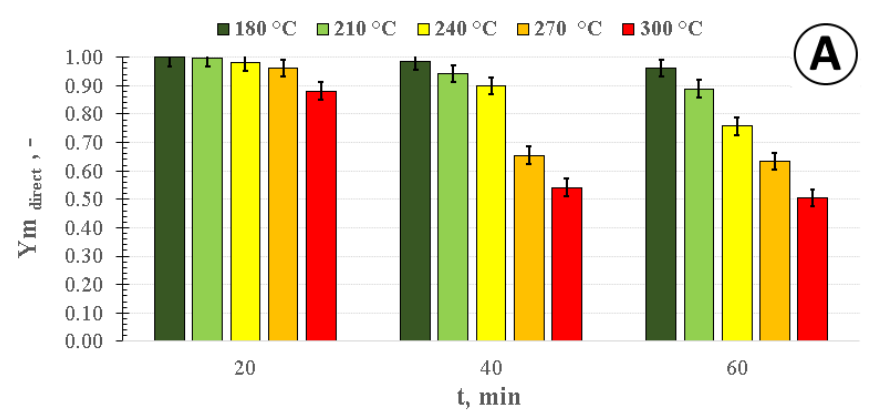

$\nabla 180^{\circ} \mathrm{C} \quad \square 210^{\circ} \mathrm{C} \quad \square 240^{\circ} \mathrm{C} \quad \square 270{ }^{\circ} \mathrm{C} \quad \nabla 300^{\circ} \mathrm{C}$
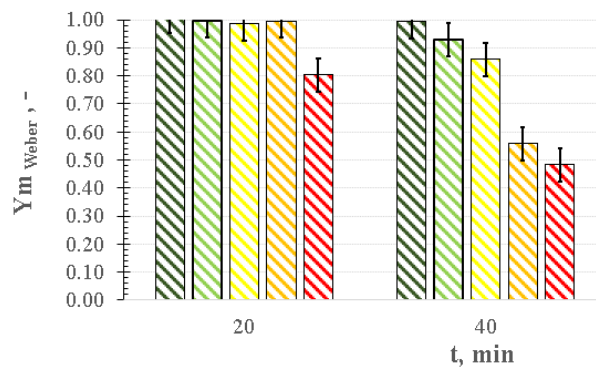

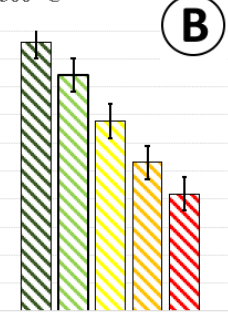

60

(B)

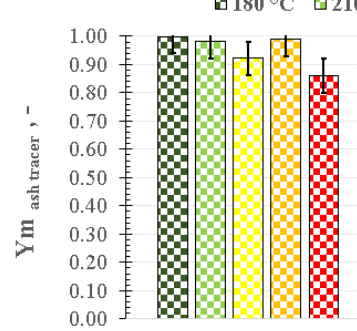

20

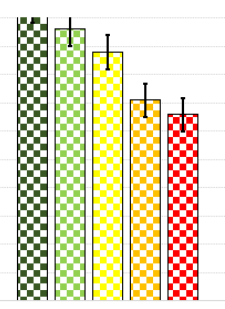

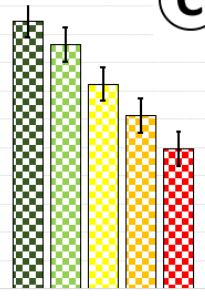

60

Figure 2. Mass yield for the torrefaction of BSG (A—direct method, B-Weber method, C—ash tracer method).

Direct comparison of the results presented in this study with the literature is not possible due to the lack of results available for the torrefaction of BSG. Work published on wet torrefaction reported substantially lower mass yields compared to the results obtained within the scope of this paper. Jackowski et al. [34] reported a mass yield of 0.809 for wet torrefaction of BSG, obtained from the brewing of beer using a mixture of pilsner, Munich and dark malt, carbonized at $200^{\circ} \mathrm{C}$ for $150 \mathrm{~min}$ [34]. In another work, Jackowski et al. [82] performed wet torrefaction of BSG from two types of beer, one brewed using barley-based pilsener malt, with the addition of some juniper, and the other wheat-based, using wheat malt, with the addition of pilsener and caramel malt [82]. HTC of barley-based beer BSG at $180^{\circ} \mathrm{C}$ for $10 \mathrm{~min}$ resulted in a mass yield slightly higher than 0.8 , whereas the increase of the process temperature up to $200^{\circ} \mathrm{C}$ resulted in the mass yield reaching 0.6 [82]. HTC of wheat-based beer BSG, performed at $200{ }^{\circ} \mathrm{C}$ for $60 \mathrm{~min}$, resulted in a mass yield slightly lower than 0.6 [82]. This is not surprising, as the yield of wet torrefaction is much higher than dry torrefaction for similar process conditions [101-104]. Such behaviour could be attributed to different reaction pathways for wet torrefaction and probably to some extent to the excellent heat conductivity of water, enhancing the delivery of heat to the whole batch of feedstock when the HTC process is compared with dry torrefaction.

Looking at the assessment of the mass yield using indirect methods, both the ash tracer (see Figure 2) and the Weber method (see Figure 2) seem to give satisfactory results, with predicted mass yields reasonably close to the values obtained directly from the experiments (Figure 2). This is different to wet torrefaction, as the ash tracer method was reported to be unsuitable for this purpose by Jackowski et al. [82]. However, in the case of dry torrefaction, ash is not partially washed out, as is often the case for wet torrefaction $[105,106]$.

Energy yield and its predictions, based on $Y_{m}$ determined using ash tracer and Weber method, show that most of the primary chemical energy in BSG should be retained in the torrefied product after the process, for most of the process conditions (Figure 3). This is beneficial from the point of view of the product. However, this might suggest that relatively high torrefaction temperatures would be needed to achieve an autothermal process. As a consequence of not being able to achieve an autothermal process, a part of the product would be needed to supply the process with all necessary heat to maintain the sustainable character of the process. More research on the heat demand for torrefaction of BSG would be needed to give more specific guidance on the process conditions allowing autothermal torrefaction, as it has been reported for other materials, such as wood [107]. 
Generally speaking, for a mild severity of process conditions, it seems plausible to expect that combustion of torgas could not be the sole source of heat for the process.
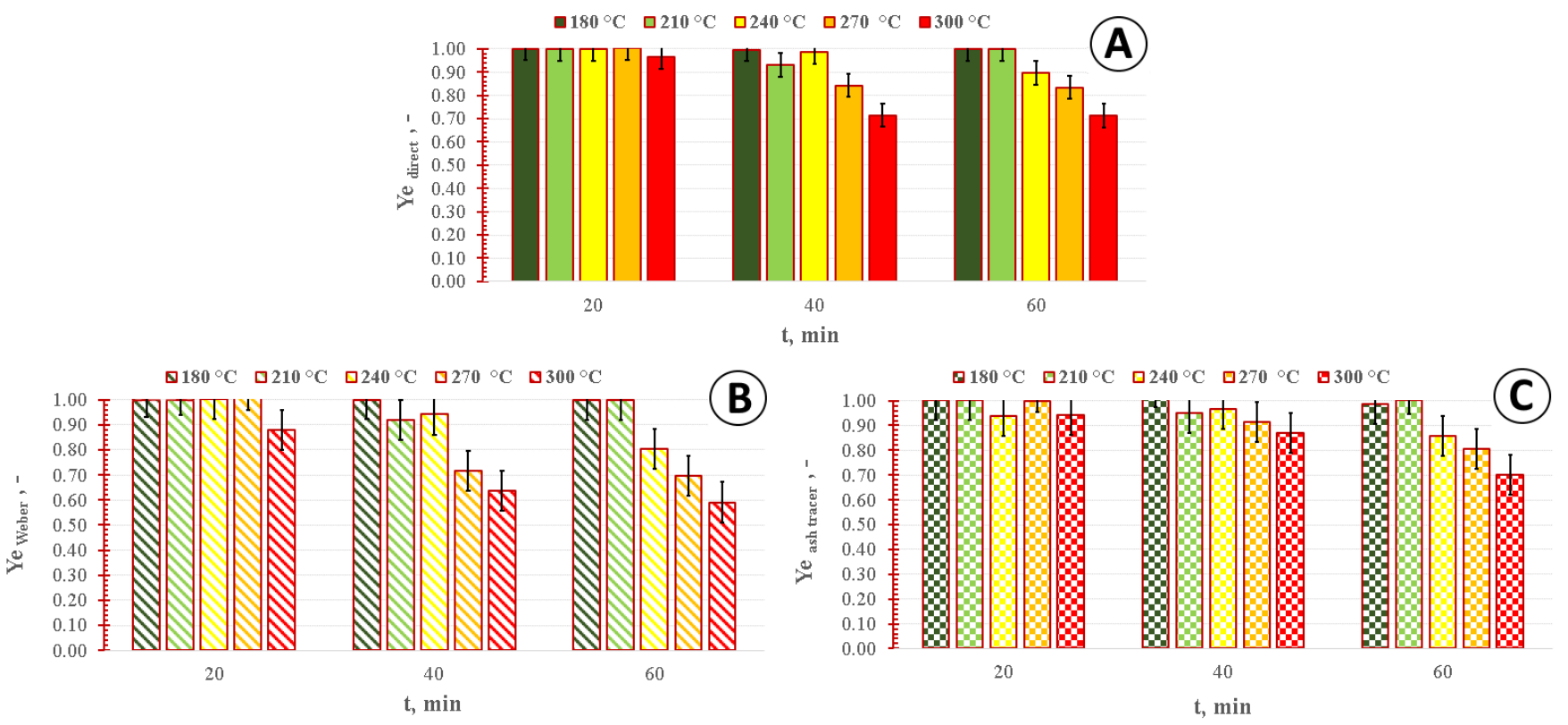

Figure 3. Energy yield for the torrefaction of BSG (based on mass yield determined by: A—direct method, B-Weber method, C-ash tracer method).

\subsection{Torrefied BSG as a Solid Fuel}

As expected, torrefaction of BSG led to an increased fixed carbon content and decreased volatile matter content (Figure 4). The effect was especially profound for higher-severity torrefaction conditions (Figure 4). This is well in line with the published sources $[42,108,109]$. As a consequence of partial loss of volatiles, ash content was also a subject of increase. The ultimate analysis shows that the carbon content increased, whereas oxygen content decreased (Figure 5). A decrease in hydrogen content was also observed (Figure 5), which could be attributed to dehydration. Higher heating value (HHV) also increased as an effect of BSG torrefaction (Figure 6), as could be reasonably expected, based on the published literature $[42,108,110]$.

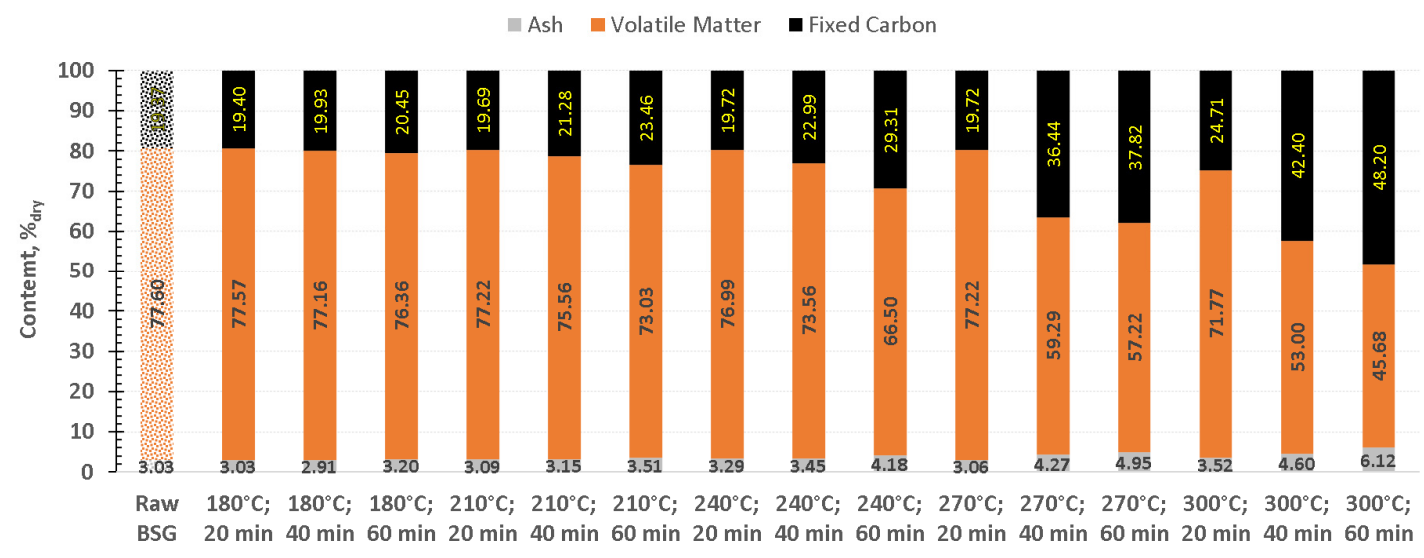

Figure 4. Proximate analysis of torrefied BSG. 


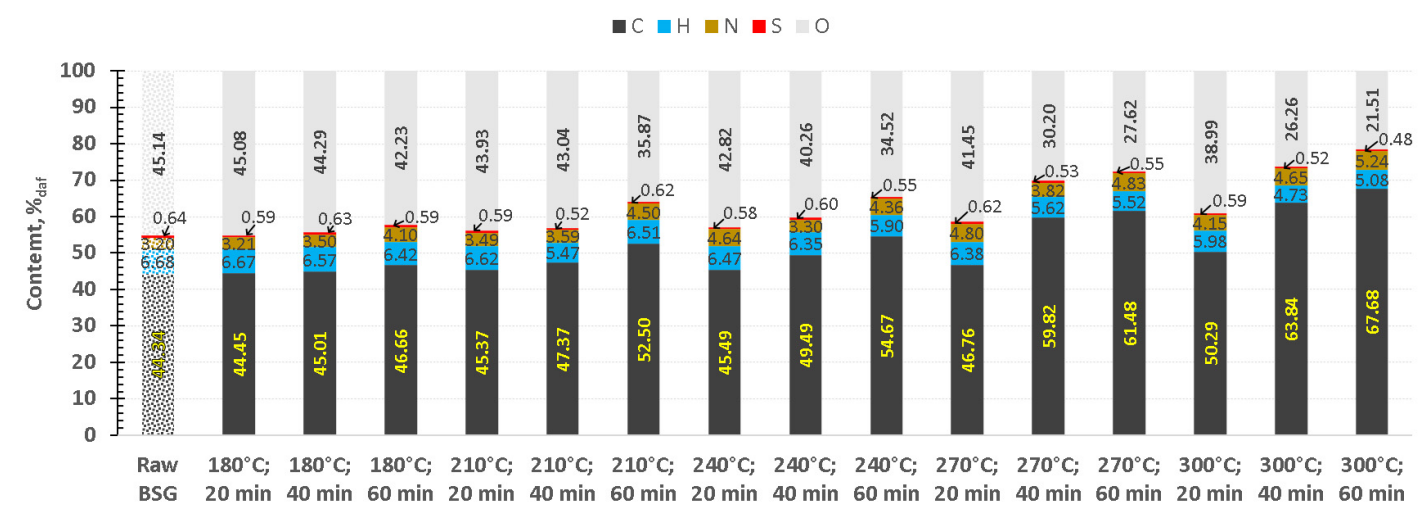

Figure 5. Ultimate analysis of torrefied BSG.

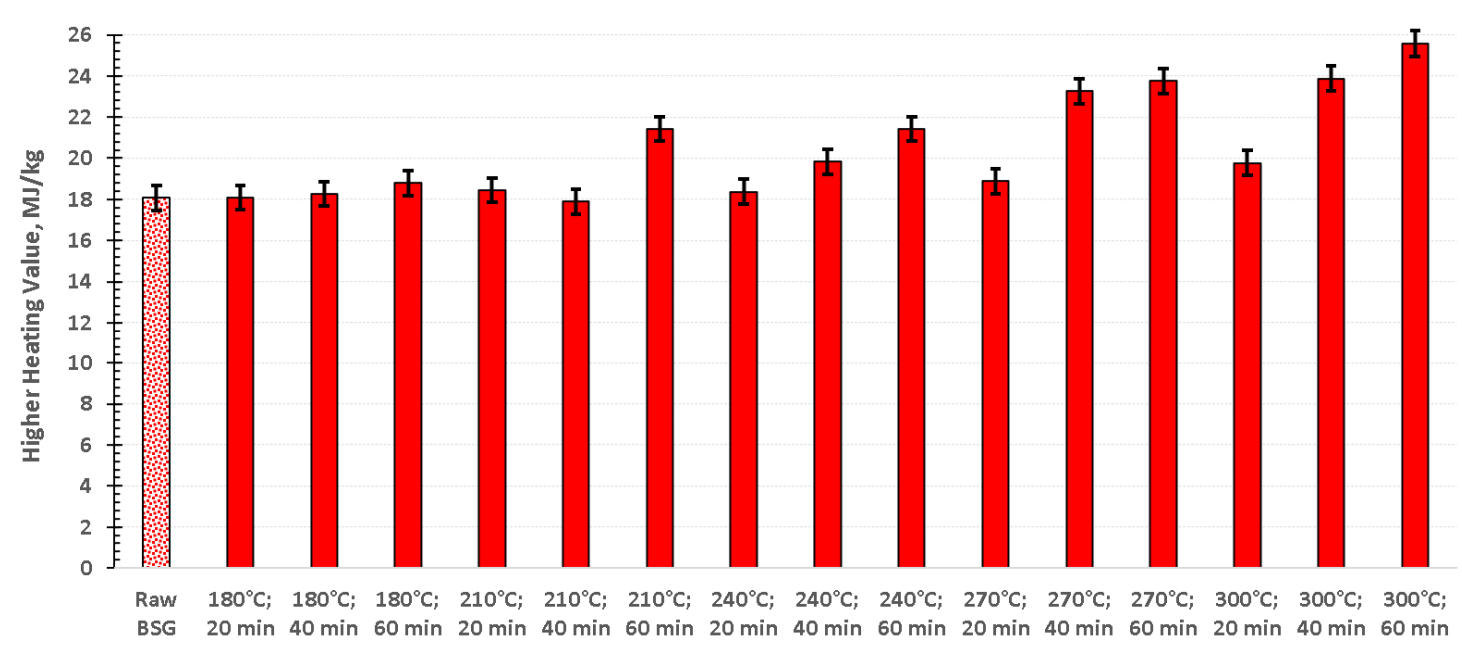

Figure 6. Higher Heating Value of torrefied BSG.

The torrefaction process caused a significant decrease of $\mathrm{H} / \mathrm{C}$ and $\mathrm{O} / \mathrm{C}$ molar ratios for torrefied BSG, as depicted in Van Krevelen's diagram (Figure 7). The diagram (Figure 7) clearly shows that valorized biomass becomes more similar to coal with increased severity of torrefaction. Relatively severe torrefaction conditions (temperature between $270{ }^{\circ} \mathrm{C}$ and $300{ }^{\circ} \mathrm{C}$ and residence time between 40 and $60 \mathrm{~min}$ ) resulted in a BSG biocoal composition similar to lignite and low-quality hard coal (Figure 7). This confirms trends observed in the literature for other torrefied materials. A similar trend, in terms of the direction of change for torrefied material, was observed by Brachi et al. [111] for torrefaction of tomato peels. However, in this case, the raw biomass had a much lower $\mathrm{O} / \mathrm{C}$ and $\mathrm{H} / \mathrm{C}$ ratio prior to valorization, and the change was not as extensive as in the case of this study [111]. Similarly, the trend was overall maintained in torrefaction of grape pomace, reported by Botelho et al. [61], despite the significantly different location of the feedstock on Van Krevelen's diagram. The location of raw BSG on Van Krevelen's diagram seems to be in good agreement with the area typical for carbohydrates, as depicted by Trubetskaya et al. [112]. This seems sensible, as BSG would consist mainly of fibre, with small amounts of residual sugars. BSG could contain some proteins, which generally has lower $\mathrm{O} / \mathrm{C}$ in comparison to carbohydrates [112]. However, thr relatively low N content (Figure 5) suggests that the content of proteins was not significant. Similar trends, in terms of the location on Van Krevelen's diagram with increased severity of torrefaction, were observed for various lignocellulosic species of biomass, such as wood [113,114], beechwood [115], miscanthus [115], Sida hermafrodita [97], Erianthus arundinaceus [96], pepper pellets [114], perilla stem pellets [114], and Kenaf [116]. 
Looking at the results obtained within the course of this study (Figure 7), it can be observed that dehydration dominated, which makes it plausible to suspect that a significant amount of hydroxyl groups were removed. Such loss of hydroxyl groups could potentially contribute to the hydrophobic character of torrefied products [111,117-119].

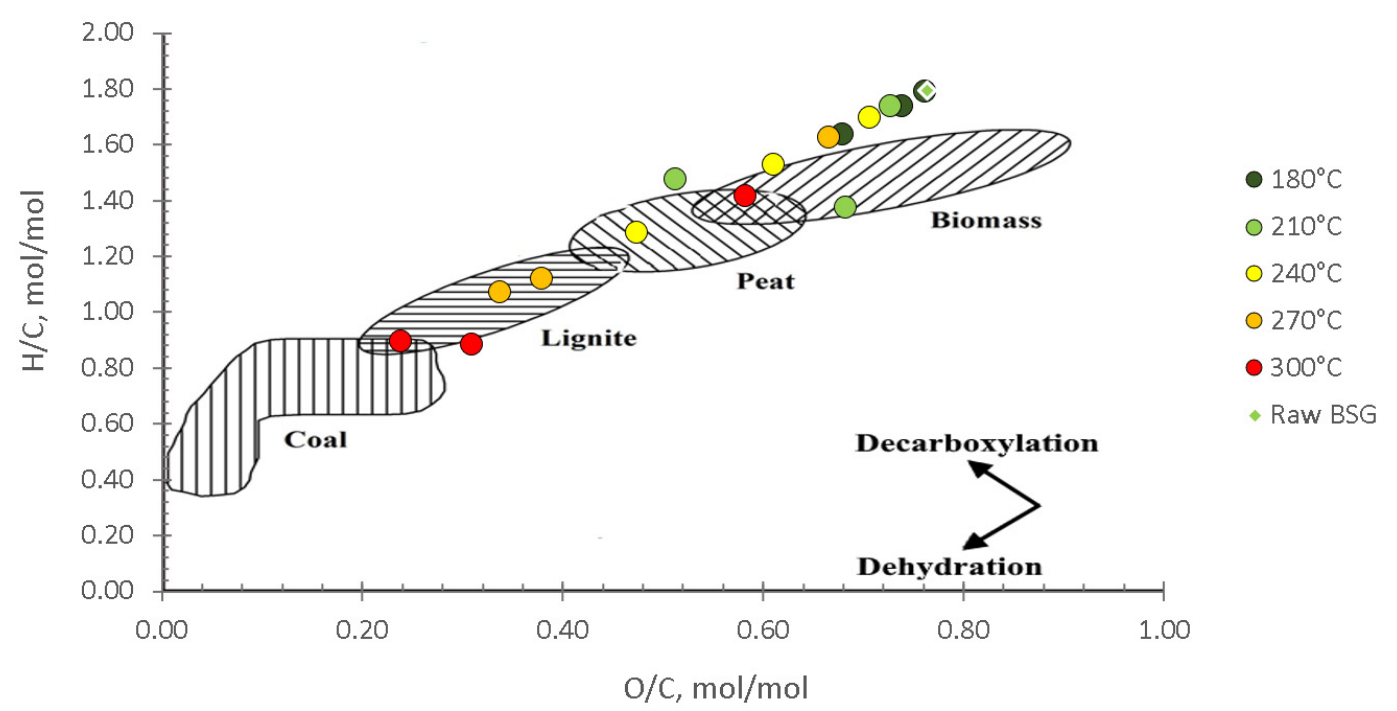

Figure 7. Torrefied BSG on Van Krevelens' diagram (locations of different solid fuels adapted from [42,61,97,111,115,120]).

\subsection{Torrefied BSG as a Beer Colouring Agent}

The results show that $\mathrm{BSG}$ roasted at $180{ }^{\circ} \mathrm{C}$ for $60 \mathrm{~min}$ and $210{ }^{\circ} \mathrm{C}$ for $40 \mathrm{~min}$ have the best colouring properties, reaching an EBC colour value of 145 and 159, respectively (Figure 8). These temperatures are slightly higher than the roasting temperature of Chocolate malt and slightly lower than roasting temperature of black malt, with a roasting time of $90 \mathrm{~min}$, as reported by Ekielski et al. [121]. This suggests that the initial content of sugars also profoundly influences the colouring properties of the produced colouring agent. Although the colour of the roasted BSG produced within the course of this study, is two times less intense than those obtained from dark malt, the use of the spent grains could still prove beneficial since, in such a scenario, process residues would be used. Moreover, the addition of roasted spent grains may help in the formation of filtration cake during lautering. That, in turn, could positively contribute to the wort filtration process.

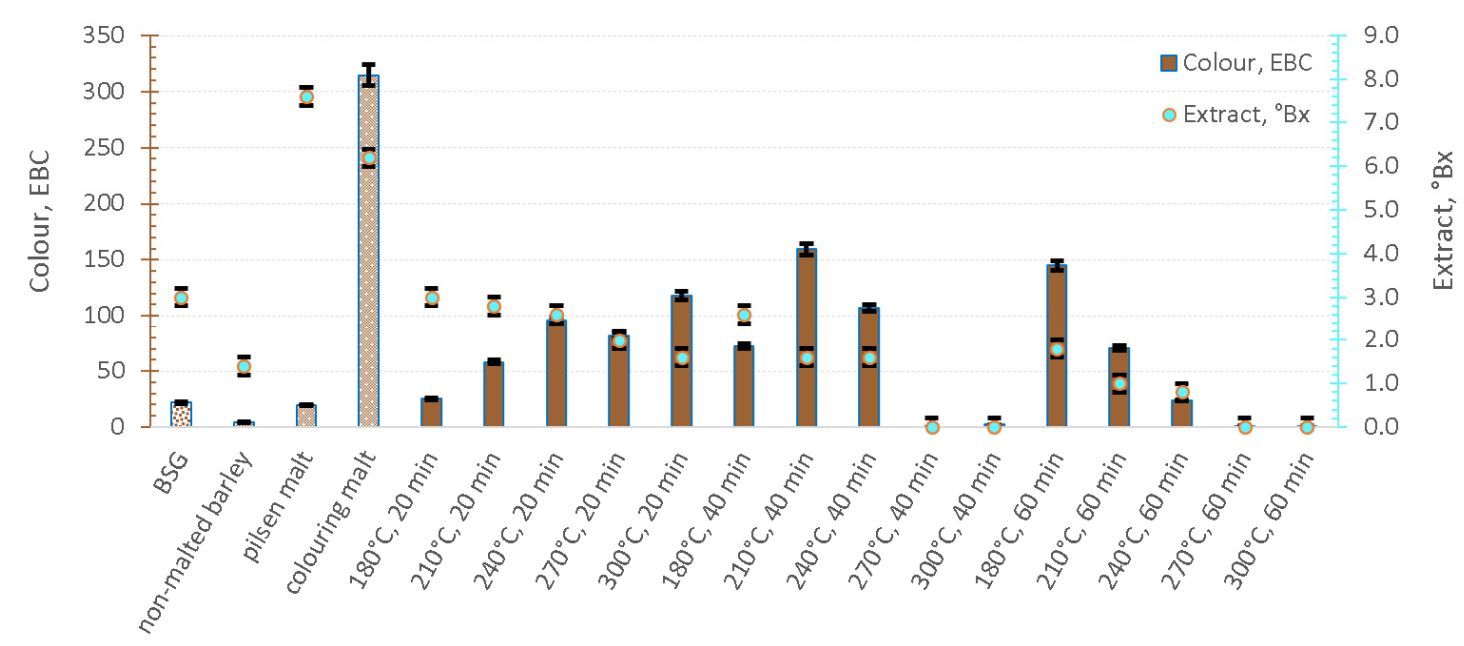

Figure 8. Colouring properties and content of sugars in raw and torrefied BSG, as well as colouring malt (typically used to change colour), pilsen malt and non-malted barley. The bar graph shows colour in EBC scale, whereas points show values of extract in ${ }^{\circ} \mathrm{Bx}$ (Brix). 
Another benefit of using torrefied BSG, apart from its colouring properties, is the profile of flavours and aromas (see Table 1) that could enrich the taste experience of a particular beer. Same as in the case of colouring properties, severe torrefaction conditions resulted in unwanted charcoal flavour. However, in some cases, flavours and aromas from sweet/fruity (mild torrefaction conditions) to whiskey/chocolate/coffee (moderate torrefaction conditions) could be sensed. Obtaining a more profound and more unique flavour could be one of the advantages from a commercial perspective.

Table 1. Flavour/aroma profile of torrefied brewers' spent grains.

\begin{tabular}{ccc}
\hline $\begin{array}{c}\text { Temperature } \\
{\left[{ }^{\circ} \mathrm{C}\right]}\end{array}$ & $\begin{array}{c}\text { Time } \\
{[\text { min] }}\end{array}$ & Aroma \\
\hline \multirow{2}{*}{180} & 20 & cereal \\
& 40 & sweet \\
& 60 & dried plum \\
210 & 20 & dried fruits \\
& 40 & wood \\
240 & 60 & whisky \\
& 20 & sweet/cereal \\
& 40 & roasted/wood \\
270 & 60 & charcoal \\
& 20 & chocolate/cocoa \\
& 40 & roasted \\
& 60 & charcoal \\
& 20 & whisky/coffee \\
& 40 & charcoal \\
& 60 & charcoal \\
\hline
\end{tabular}

\subsection{Proposed Way of Integration of Torrefaction of BSG for Improved Sustainability of a Brewery}

It is clear, taking into consideration both the EBC (Figure 8) and HHV of torrefied BSG (Figure 6), that achieving maximum synergy between roasting for production of colouring agent and production of solid fuel is extremely difficult. This complicates the selection of the optimum parameters of the torrefaction process. It seems plausible to assume that condensable products of torrefaction, present at the surface of the particles, are responsible for the colouring effect. For example, Cruz-Ceballos et al. [122] hypothesized that condensed hydrocarbons could be responsible for blocking the active oxidation sites on the particle surface. Some of the literature sources, such as Das et al. [123] and Gray et al. [124], mention condensed hydrocarbons as a potential factor relevant to the hydrophobic behaviour of thermally treated solids. However, in the case of highly hydrophobic compounds, it would be difficult to expect high solubility in water, which would be needed, especially for achieving darker colours. On the other hand, the presence of the Maillard reaction products was confirmed in roasted malts by Herdt et al. [125]. It seems plausible to assume that the Maillard reaction products that form during torrefaction of BSG [38] have the most profound influence on the colouring properties of colouring agents used in brewing [39]. Therefore, decomposition of these compounds could be considered the leading cause of the poor colouring properties of the BSG torrefied in more severe process conditions. This imposes important limitations on the extent of the improvement of the fuel properties due to torrefaction if the dual purpose is considered, i.e., using part of the torrefied BSG stream as a colouring agent and part as a solid fuel. Nonetheless, it should not be overlooked that even mild torrefaction of BSG results in relatively good solid fuel.

Figure 9 shows the proposed sustainable way of integration of torrefaction of BSG into a brewery. Since only torrefaction of BSG at relatively mild conditions could be used to produce a reasonably applicable colouring agent, it is reasonable to expect that it will be difficult to achieve an autothermal process. Therefore, a part of the torrefied product would be needed to supply a part of the heat needed for the torrefaction process. 


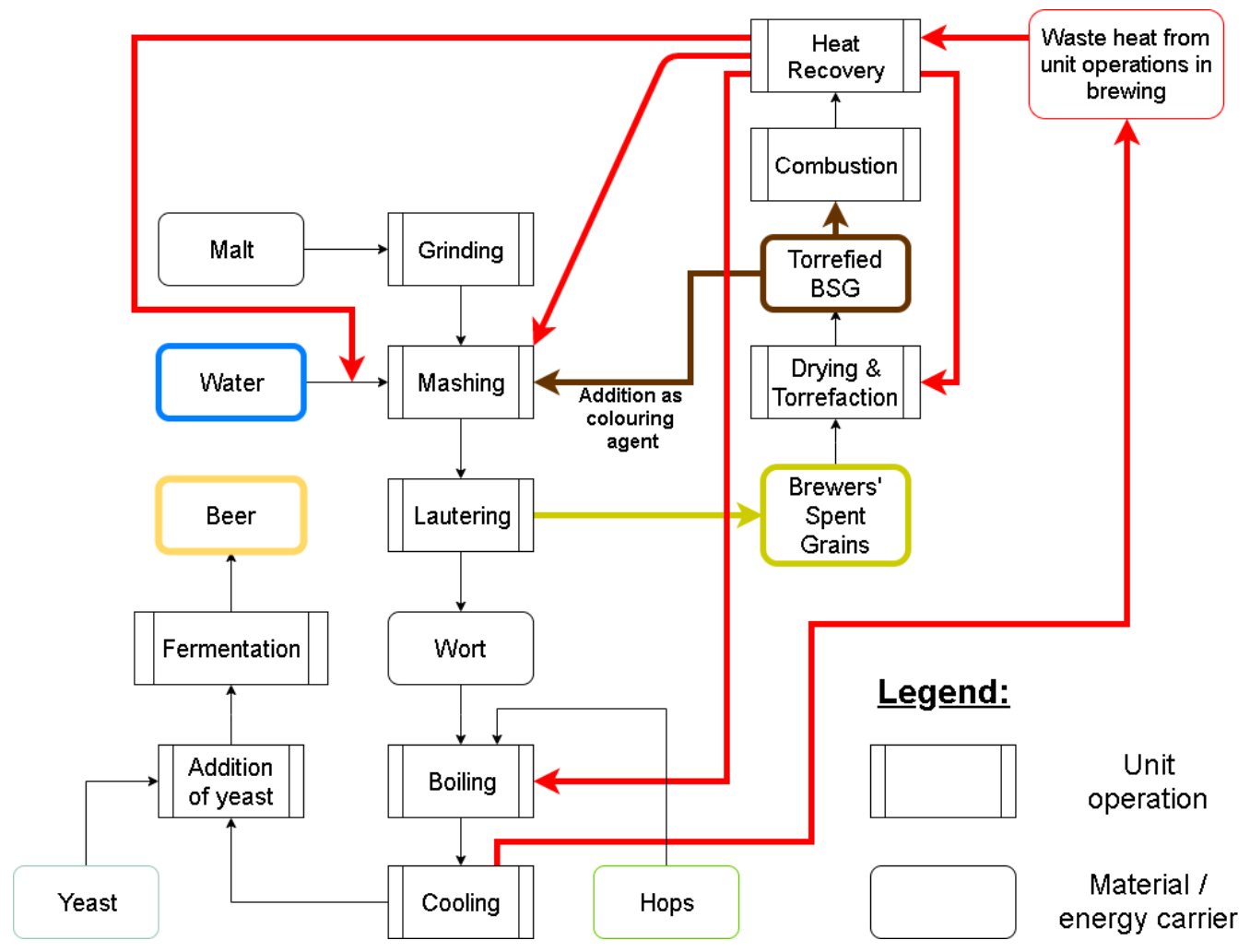

Figure 9. A diagram of a brewery with integrated torrefaction of BSG.

Although beer recipes differ from brewery to brewery, it is possible to estimate the consumption of torrefied brewers' spent grains for brewing, which could also show how much would be left for energy purposes. For instance, for pale beers like pils, lager, pale ale or wheat beer, the addition of roasted BSG as a colouring agent is not necessary. For beers like Brown ale, adding 1\% to $3 \%$ of dark malt is recommended [126]. In a small brewery, approximately $22 \mathrm{~kg}$ of malt is needed to prepare $1 \mathrm{hL}$ of wort with a sugar content of $14{ }^{\circ} \mathrm{Bx}$. Those numbers may depend on malt quality and mashing regime. To prepare $1 \mathrm{hL}$ of Brown ale with $14{ }^{\circ} \mathrm{Bx}$ extract, using $3 \%$ of dark malt, a $0.66 \mathrm{~g}$ of dark malt would be needed. According to the EBC values (Figure 8), approximately two times more torrefied BSG (torrefied at $210{ }^{\circ} \mathrm{C}$ for $40 \mathrm{~min}$ ) would be needed to obtain a similar colour, which translates to $1.32 \mathrm{~kg}$ of BSG roasted at a temperature of $210^{\circ} \mathrm{C}$ for $40 \mathrm{~min}$. In the case of stronger, darker beers, such as Foreign extra stout, it is recommended to use up to $10 \%$ dark malt [126]. To prepare $1 \mathrm{hL}$ of wort with $16^{\circ} \mathrm{Bx}$ extract (this value is higher than for brown ale due to the recommendations of the style $[3,126])$, approximately $30 \mathrm{~kg}$ of raw material would be needed. Among used malts, $3 \mathrm{~kg}$ of dark malt is typically included $[3,126]$. Dark malt could be replaced by $6 \mathrm{~kg}$ of BSG roasted at $210{ }^{\circ} \mathrm{C}$ for $40 \mathrm{~min}$. The BSG left after brewing of Brown ale, and Foreign extra stout would be approximately $12.0 \mathrm{~kg}$ and $19.5 \mathrm{~kg}$, respectively. Taking $Y_{m}$ for torrefaction at $210{ }^{\circ} \mathrm{C}$ for $40 \mathrm{~min}$ into account, $11.7 \%$ of the torrefied BSG would be needed for colouring of the beer, whereas the remaining $88.3 \%$ of the torrefied residues could be used for energy purposes. In the case of Foreign extra stout, only $67.3 \%$ of the torrefied BSG could be used for energy purposes, despite a higher amount of BSG left after lautering, owing to a much higher demand for colouring. Nonetheless, for $1 \mathrm{hL}$ of beer, approx. $185 \mathrm{MJ}$ and $229 \mathrm{MJ}$ of primary energy would be available for energy purposes for Brown ale and Foreign extra stout cases, respectively. This is significant, as Mainardis et al. [127] estimated the heat requirement per $1 \mathrm{hL}$ of beer to vary between 116.4-147.0 MJ/hL [127] and electricity requirement ranging between 130.6-148.9 MJ/hL [127]. Overall, Mainardis et al. [127] reported a biomethane potential of $486.9 \mathrm{dm}^{3}{ }_{\mathrm{N}} \mathrm{CH}_{4} / \mathrm{kg}$ and $356.2 \mathrm{dm}^{3}{ }_{\mathrm{N}} \mathrm{CH}_{4} / \mathrm{kg}$ for spent yeast and BSG, respectively, 
and concluded that the anaerobic digestion of spent yeast and spent grain in proportion $70 / 30$ could supply $53.9 \%$ of electric and $64.4 \%$ of the thermal need of a brewery [127]. In the configuration proposed in this work, roasted BSG not used for colouring could be gasified in a CHP unit to supply both electricity and heat or combusted if heat supply is the most crucial concern. Without any doubt, waste heat recovery would be necessary, as drying of the BSG with an initial moisture content of $70 \%-75 \%$ is indeed an energyintensive process. Nonetheless, waste heat recovery (Figure 9) could supply at least a part of the required heat. Furthermore, it should not be overlooked that the spent yeast would still be available as feedstock for biogas production, which had approx. $35 \%$ higher BMP compared to the BSG, as reported by Mainardis et al. [127]. Additionally, enriching producer gas with methane is beneficial in terms of its combustion in spark-ignited engines, as reported by Szwaja et al. [128]. It seems to be reasonable to recommend further research on the optimisation of the concept from an energy-efficiency perspective, as well as on its economic feasibility.

It is not possible to perform a complete energy balance at this point, as more information is needed on the heat required for drying of the BSG prior to torrefaction or the amount of waste heat for drying that could be recovered from different stages of the brewing process. In the end, supplying $100 \%$ of the brewery's own needs using self-produced residues might not be possible. Nonetheless, even partial reduction of the carbon footprint could be considered positive. Moreover, from a sustainability perspective, it seems hard to deny that the on-site use of residues from the brewing process would have an overall positive influence, as the cost and the emissions associated with transportation of BSG to alternative consumers (e.g., farmers) cannot be considered negligible. Moreover, savings related to decreased demand of the brewery for the malt should also be taken into account, as well environmental benefits related to cutting the emissions related to transportation of the roasted malt. Raw materials contribute $22 \%$ of the overall carbon footprint across the complete beer production and distribution chain [129]. Moreover, economic benefits provided by a possibility to cut the cost, by not needing to purchase the malt and using own residues, should be considered beneficial.

Overall, it should not be overlooked that such practical implementation of the "Reduce, reuse, recycle" approach certainly contributes to implementing the rules of the circular economy in the brewing industry. Further research is necessary concerning different aspects of the concept, including its further optimization, as the benefits could be definitely confirmed by a comprehensive Life Cycle Assessment, for which more data would be required. Since it is likely that the BSG would not be sufficient for supplying $100 \%$ of the energy needs of such installation, further research on co-firing and co-gasification of torrefied BSG with various types of raw/torrefied biomass also seems to be a reasonable recommendation, as such dual fuel systems could be a viable way of achieving carbon neutrality by breweries in the future.

\section{Conclusions}

On-site implementation of torrefaction of BSG at breweries seems to bring some crucial advantages from a sustainability perspective. However, severe torrefaction conditions are more advantageous from a solid fuel perspective, whereas mild torrefaction conditions are advantageous from the point of view of using torrefied BSG as a colouring agent. For the most severe torrefaction conditions $\left(300{ }^{\circ} \mathrm{C}, 60 \mathrm{~min}\right)$ the higher heating value of torrefied BSG reached $25 \mathrm{MJ} / \mathrm{kg}$. However, the best beer colouring properties were achieved for mild torrefaction conditions, i.e., $180^{\circ} \mathrm{C}$ for $60 \mathrm{~min}$ and $210^{\circ} \mathrm{C}$ for $40 \mathrm{~min}$, reaching an EBC of 145 and 159, respectively. Nonetheless, BSG torrefied in such process conditions is not very different from typical solid biofuels, such as wood pellets. Overall, the obtained results suggest some trade-off between the optimum colouring properties and optimum solid fuel properties that need to be considered when such dual-purpose torrefaction of BSG for brewery purposes is implemented. More research is needed in order to investigate the optimum conditions for BSG from many different types of beer since variables such as 
different compositions of BSG, different content of residual sugars might have a significant influence on the optimum conditions of the torrefaction process from the perspective of colouring properties and flavour/aroma profile.

Author Contributions: Conceptualization: M.J., Ł.N. and K.M.; methodology: M.J., Ł.N. and K.M.; validation: M.J., M.L., A.A., K.K. and M.A.S.; formal analysis: M.J. and Ł.N.; investigation: J.P., K.M., M.L., K.K., J.Č., J.S., J.V.; resources: Ł.N., H.P.-K., A.T., T.O.; data curation: J.P., A.A., K.K., and M.A.S.; writing—original draft preparation: Ł.N. and M.J.; writing—review and editing: Ł.N., M.J., J.Č., M.A.S., A.A.; visualization: J.S., J.V., A.A., M.L., M.A.S. and J.P.; supervision: Ł.N., H.P.-K., A.T., T.O., K.M.; project administration: Ł.N.; funding acquisition: Ł.N. All authors have read and agreed to the published version of the manuscript.

Funding: Financial support of this research from the National Science Centre, Poland-project no. 2019/33/N/ST8/02641, is gratefully acknowledged.

Institutional Review Board Statement: Not applicable.

Informed Consent Statement: Not applicable.

Conflicts of Interest: The authors declare no conflict of interest. The funders had no role in the design of the study; in the collection, analyses, or interpretation of data; in the writing of the manuscript, or in the decision to publish the results.

\section{References}

1. Hornsey, I.S. History of Beer and Brewing; RSC Publishing: London, UK, 2003; ISBN 978-0-85404-630-0.

2. Dietrich, L.; Götting-Martin, E.; Hertzog, J.; Schmitt-Kopplin, P.; McGovern, P.E.; Hall, G.R.; Petersen, W.C.; Zarnkow, M.; Hutzler, M.; Jacob, F.; et al. Investigating the function of Pre-Pottery Neolithic stone troughs from Göbekli Tepe-An integrated approach. J. Archaeol. Sci. Rep. 2020, 34, 102618. [CrossRef]

3. Mallet, J. Malt A Practical Guide from Field to Brewhouse; Brewers Publications: Boulder, CO, USA, 2014; ISBN 978-1-938469-12-1.

4. Hlavacek, F.; Lhotsky, A. Piwowarstwo; Wydawnictwo Naukowo Techniczne: Warszawa, Poland, 1969.

5. Lewis, M.; Young, T. Piwowarstwo; Mostowik, K., Ed.; Wydawnictwo Naukowe PWN S.A.: Warszawa, Poland, 2001; ISBN 83-01-13472-0.

6. Jackowski, M.; Niedzwiecki, L.; Jagiełło, K.; Uchańska, O.; Trusek, A. Brewer’s Spent Grains—Valuable Beer Industry By-Product. Biomolecules 2020, 10, 1669. [CrossRef]

7. Chetrariu, A.; Dabija, A. Brewer's spent grains: Possibilities of valorization, a review. Appl. Sci. 2020, 10, 5619. [CrossRef]

8. Özvural, E.B.; Vural, H.; Gökbulut, İ.; Özboy-Özbaş, Ö. Utilization of brewer's spent grain in the production of Frankfurters. Int. J. Food Sci. Technol. 2009, 44, 1093-1099. [CrossRef]

9. Stojceska, V.; Ainsworth, P. The effect of different enzymes on the quality of high-fibre enriched brewer's spent grain breads. Food Chem. 2008, 110, 865-872. [CrossRef]

10. Nocente, F.; Taddei, F.; Galassi, E.; Gazza, L. Upcycling of brewers' spent grain by production of dry pasta with higher nutritional potential. LWT 2019, 114, 108421. [CrossRef]

11. Amoriello, T.; Mellara, F.; Galli, V.; Amoriello, M.; Ciccoritti, R. Technological Properties and Consumer Acceptability of Bakery Products Enriched with Brewers' Spent Grains. Foods 2020, 9, 1492. [CrossRef]

12. Tan, Y.X.; Mok, W.K.; Lee, J.; Kim, J.; Chen, W.N. Solid state fermentation of Brewers' spent grains for improved nutritional profile using Bacillus subtilis WX-17. Fermentation 2019, 5, 52. [CrossRef]

13. Zuorro, A.; Iannone, A.; Lavecchia, R. Water-organic solvent extraction of phenolic antioxidants from brewers' spent grain. Processes 2019, 7, 126. [CrossRef]

14. Alonso-Riaño, P.; Sanz Diez, M.T.; Blanco, B.; Beltrán, S.; Trigueros, E.; Benito-Román, O. Water Ultrasound-Assisted Extraction of Polyphenol Compounds from Brewer's Spent Grain: Kinetic Study, Extract Characterization, and Concentration. Antioxidants 2020, 9, 265. [CrossRef]

15. Birsan, R.I.; Wilde, P.; Waldron, K.W.; Rai, D.K. Recovery of polyphenols from brewer's spent grains. Antioxidants 2019, 8, 380. [CrossRef] [PubMed]

16. Du, L.; Arauzo, P.J.; Meza Zavala, M.F.; Cao, Z.; Olszewski, M.P.; Kruse, A. Towards the properties of different biomass-derived proteins via various extraction methods. Molecules 2020, 25, 488. [CrossRef]

17. Lordan, R.; O'Keeffe, E.; Tsoupras, A.; Zabetakis, I. Total, neutral, and polar lipids of brewing ingredients, by-products and beer: Evaluation of antithrombotic activities. Foods 2019, 8, 171. [CrossRef] [PubMed]

18. Ferreira, A.M.; Martins, J.; Carvalho, L.H.; Magalhães, F.D. Biosourced disposable trays made of brewer's spent grain and potato starch. Polymers 2019, 11, 923. [CrossRef]

19. Zedler, Ł.; Colom, X.; Cañavate, J.; Saeb, M.R.; Haponiuk, J.T.; Formela, K. Investigating the Impact of Curing System on Structure-Property Relationship of Natural Rubber Modified with Brewery By-Product and Ground Tire Rubber. Polymers 2020, 12, 545. [CrossRef] 
20. Mancini, S.; Fratini, F.; Turchi, B.; Mattioli, S.; Dal Bosco, A.; Tuccinardi, T.; Nozic, S.; Paci, G. Former foodstuff products in Tenebrio molitor rearing: Effects on growth, chemical composition, microbiological load, and antioxidant status. Animals 2019, 9, 484. [CrossRef] [PubMed]

21. Silbir, S.; Goksungur, Y. Natural red pigment production by monascus purpureus in submerged fermentation systems using a food industry waste: Brewer's spent grain. Foods 2019, 8, 161. [CrossRef]

22. Amoriello, T.; Fiorentino, S.; Vecchiarelli, V.; Pagano, M. Evaluation of spent grain biochar impact on hop (Humulus lupulus L.) growth by multivariate image analysis. Appl. Sci. 2020, 10, 533. [CrossRef]

23. Cancelliere, R.; Carbone, K.; Pagano, M.; Cacciotti, I.; Micheli, L. Biochar from brewers' spent grain: A green and low-cost smart material to modify screen-printed electrodes. Biosensors 2019, 9, 139. [CrossRef]

24. Ahmed, I.; Zia, M.A.; Afzal, H.; Ahmed, S.; Ahmad, M.; Akram, Z.; Sher, F.; Iqbal, H.M.N. Socio-economic and environmental impacts of biomass valorisation: A strategic drive for sustainable bioeconomy. Sustainability 2021, 13, 4200. [CrossRef]

25. Tzelepi, V.; Zeneli, M.; Kourkoumpas, D.S.; Karampinis, E.; Gypakis, A.; Nikolopoulos, N.; Grammelis, P. Biomass availability in europe as an alternative fuel for full conversion of lignite power plants: A critical review. Energies 2020, 13, 3390. [CrossRef]

26. Meinusch, N.; Kramer, S.; Körner, O.; Wiese, J.; Seick, I.; Beblek, A.; Berges, R.; Illenberger, B.; Illenberger, M.; Uebbing, J.; et al. Integrated Cycles for Urban Biomass as a Strategy to Promote a CO2-Neutral Society-A Feasibility Study. Sustainability 2021, 13, 9505. [CrossRef]

27. Zulqarnain; Ayoub, M.; Yusoff, M.H.M.; Nazir, M.H.; Zahid, I.; Ameen, M.; Sher, F.; Floresyona, D.; Budi Nursanto, E. A Comprehensive Review on Oil Extraction and Biodiesel Production Technologies. Sustainability 2021, 13, 788. [CrossRef]

28. Mussatto, S.I. Brewer's spent grain: A valuable feedstock for industrial applications. J. Sci. Food Agric. 2014, 94, 1264-1275. [CrossRef] [PubMed]

29. Enweremadu, C.; Waheed, M.A.; Adekunle, A.A.; Adeala, A. The Energy Potential of Brewer's Spent Grain for Breweries in Nigeria. Eng. Appl. Sci. 2008, 3, 175-177.

30. Sperandio, G.; Amoriello, T.; Carbone, K.; Fedrizzi, M.; Monteleone, A.; Tarangioli, S.; Pagano, M. Increasing the value of spent grain from craft microbreweries for energy purposes. Chem. Eng. Trans. 2017, 58, 487-492. [CrossRef]

31. Liguori, R.; Soccol, C.R.; de Souza Vandenberghe, L.P.; Woiciechowski, A.L.; Faraco, V. Second generation ethanol production from brewers' spent grain. Energies 2015, 8, 2575-2586. [CrossRef]

32. Rasheed, T.; Anwar, M.T.; Ahmad, N.; Sher, F.; Khan, S.U.D.; Ahmad, A.; Khan, R.; Wazeer, I. Valorisation and emerging perspective of biomass based waste-to-energy technologies and their socio-environmental impact: A review. J. Environ. Manag. 2021, 287, 112257. [CrossRef]

33. Arauzo, P.; Olszewski, M.; Kruse, A. Hydrothermal Carbonization Brewer's Spent Grains with the Focus on Improving the Degradation of the Feedstock. Energies 2018, 11, 3226. [CrossRef]

34. Jackowski, M.; Semba, D.; Trusek, A.; Wnukowski, M.; Niedzwiecki, L.; Baranowski, M.; Krochmalny, K.; Pawlak-Kruczek, H. Hydrothermal Carbonization of Brewery's Spent Grains for the Production of Solid Biofuels. Beverages 2019, 5, 12. [CrossRef]

35. Poerschmann, J.; Weiner, B.; Wedwitschka, H.; Baskyr, I.; Koehler, R.; Kopinke, F.D. Characterization of biocoals and dissolved organic matter phases obtained upon hydrothermal carbonization of brewer's spent grain. Bioresour. Technol. 2014, 164, 162-169. [CrossRef]

36. Olszewski, M.P.; Arauzo, P.J.; Wądrzyk, M.; Kruse, A. Py-GC-MS of hydrochars produced from brewer's spent grains. J. Anal. Appl. Pyrolysis 2019, 140, 255-263. [CrossRef]

37. Ferreira, S.; Monteiro, E.; Brito, P.; Castro, C.; Calado, L.; Vilarinho, C. Experimental analysis of brewers' spent grains steam gasification in an allothermal batch reactor. Energies 2019, 12, 912. [CrossRef]

38. Dudek, M.; Świechowski, K.; Manczarski, P.; Koziel, J.A.; Białowiec, A. The effect of biochar addition on the biogas production kinetics from the anaerobic digestion of brewers' spent grain. Energies 2019, 12, 1518. [CrossRef]

39. Furukawa Suárez, A.; Kunz, T.; Cortés Rodríguez, N.; MacKinlay, J.; Hughes, P.; Methner, F.J. Impact of colour adjustment on flavour stability of pale lager beers with a range of distinct colouring agents. Food Chem. 2011, 125, 850-859. [CrossRef]

40. Reinoso-Carvalho, F.; Dakduk, S.; Wagemans, J.; Spence, C. Dark vs. light drinks: The influence of visual appearance on the consumer's experience of beer. Food Qual. Prefer. 2019, 74, 21-29. [CrossRef]

41. Nunes, L.J.R.; Matias, J.C.O. Biomass torrefaction as a key driver for the sustainable development and decarbonization of energy production. Sustainability 2020, 12, 922. [CrossRef]

42. Ribeiro, J.M.C.; Godina, R.; Matias, J.C.O.; Nunes, L.J.R. Future perspectives of biomass torrefaction: Review of the current state-of-the-art and research development. Sustainability 2018, 10, 2323. [CrossRef]

43. Thrän, D.; Witt, J.; Schaubach, K.; Kiel, J.; Carbo, M.; Maier, J.; Ndibe, C.; Koppejan, J.; Alakangas, E.; Majer, S.; et al. Moving torrefaction towards market introduction-Technical improvements and economic-environmental assessment along the overall torrefaction supply chain through the SECTOR project. Biomass Bioenergy 2016, 89, 184-200. [CrossRef]

44. Li, J.; Brzdekiewicz, A.; Yang, W.; Blasiak, W. Co-firing based on biomass torrefaction in a pulverized coal boiler with aim of $100 \%$ fuel switching. Appl. Energy 2012, 99, 344-354. [CrossRef]

45. Szufa, S. Use of superheated steam in the process of biomass torrefaction. Przem. Chem. 2020, 12, 123-127. [CrossRef]

46. Jagodzińska, K.; Czerep, M.; Kudlek, E.; Wnukowski, M.; Yang, W. Torrefaction of wheat-barley straw: Composition and toxicity of torrefaction condensates. Biomass Bioenergy 2019, 129, 105335. [CrossRef] 
47. Knapczyk, A.; Francik, S.; Jewiarz, M.; Zawiślak, A.; Francik, R. Thermal Treatment of Biomass: A Bibliometric Analysis-The Torrefaction Case. Energies 2020, 14, 162. [CrossRef]

48. Szufa, S.; Wielgosiński, G.; Piersa, P.; Czerwińska, J.; Dzikuć, M.; Adrian, Ł.; Lewandowska, W.; Marczak, M. Torrefaction of Straw from Oats and Maize for Use as a Fuel and Additive to Organic Fertilizers-TGA Analysis, Kinetics as Products for Agricultural Purposes. Energies 2020, 13, 2064. [CrossRef]

49. Lu, Z.; Jian, J.; Arendt Jensen, P.; Wu, H.; Glarborg, P. Impact of $\mathrm{KCl}$ impregnation on single particle combustion of wood and torrefied wood. Fuel 2017, 206, 684-689. [CrossRef]

50. Lu, Z.; Jian, J.; Jensen, P.A.; Wu, H.; Glarborg, P. Influence of Torrefaction on Single Particle Combustion of Wood. Energy Fuels 2016, 30, 5772-5778. [CrossRef]

51. Romanowska-Duda, Z.; Szufa, S.; Grzesik, M.; Piotrowski, K.; Janas, R. The Promotive Effect of Cyanobacteria and Chlorella sp. Foliar Biofertilization on Growth and Metabolic Activities of Willow (Salix viminalis L.) Plants as Feedstock Production, Solid Biofuel and Biochar as C Carrier for Fertilizers via Torrefaction Proce. Energies 2021, 14, 5262. [CrossRef]

52. Boylan, D.M.; Roberts, G.K.; Zemo, B.R.; Wilson, J.L. Torrefied Wood Field Tests at a Coal-Fired Power Plant. IEEE Trans. Ind. Appl. 2016, 52, 751-757. [CrossRef]

53. Lasek, J.A.; Kopczyński, M.; Janusz, M.; Iluk, A.; Zuwała, J. Combustion properties of torrefied biomass obtained from flue gas-enhanced reactor. Energy 2017, 119, 362-368. [CrossRef]

54. Sher, F.; Yaqoob, A.; Saeed, F.; Zhang, S.; Jahan, Z.; Klemeš, J.J. Torrefied biomass fuels as a renewable alternative to coal in co-firing for power generation. Energy 2020, 209, 118444. [CrossRef]

55. Junga, R.; Pospolita, J.; Niemiec, P. Combustion and grindability characteristics of palm kernel shells torre fi ed in a pilot-scale installation. Renew. Energy 2020, 147, 1239-1250. [CrossRef]

56. Pawlak-Kruczek, H.; Krochmalny, K.; Mościcki, K.; Zgóra, J.; Czerep, M.; Ostrycharczyk, M.; Niedźwiecki, Ł. Torrefaction of Various Types of Biomass in Laboratory Scale, Batch-Wise Isothermal Rotary Reactor and Pilot Scale, Continuous Multi-Stage Tape Reactor. Eng. Prot. Environ. 2017, 20, 457-472. [CrossRef]

57. Howell, A.; Beagle, E.; Belmont, E. Torrefaction of Healthy and Beetle Kill Pine and Co-Combustion With Sub-Bituminous Coal. J. Energy Resour. Technol. 2017, 140, 042002. [CrossRef]

58. Repellin, V.; Govin, A.; Rolland, M.; Guyonnet, R. Energy requirement for fine grinding of torrefied wood. Biomass Bioenergy 2010, 34, 923-930. [CrossRef]

59. Martín-Pascual, J.; Jódar, J.; Rodríguez, M.L.; Zamorano, M. Determination of the optimal operative conditions for the torrefaction of olive waste biomass. Sustainbility 2020, 12, 6411. [CrossRef]

60. Szufa, S.; Piersa, P.; Adrian, Ł.; Czerwińska, J.; Lewandowski, A.; Lewandowska, W.; Sielski, J.; Dzikuć, M.; Wróbel, M.; Jewiarz, M.; et al. Sustainable Drying and Torrefaction Processes of Miscanthus for Use as a Pelletized Solid Biofuel and Biocarbon-Carrier for Fertilizers. Molecules 2021, 26, 1014. [CrossRef]

61. Botelho, T.; Costa, M.; Wilk, M.; Magdziarz, A. Evaluation of the combustion characteristics of raw and torrefied grape pomace in a thermogravimetric analyzer and in a drop tube furnace. Fuel 2018, 212, 95-100. [CrossRef]

62. Wilk, M.; Magdziarz, A.; Kalemba, I. Characterisation of renewable fuels' torrefaction process with different instrumental techniques. Energy 2015, 87, 259-269. [CrossRef]

63. Anca-Couce, A.; Caposciutti, G.; Gruber, T.; Kelz, J.; Bauer, T.; Hochenauer, C.; Scharler, R. Single large wood log conversion in a stove: Experiments and modelling. Renew. Energy 2019, 143, 890-897. [CrossRef]

64. Kantorek, M.; Jesionek, K.; Polesek-Karczewska, S.; Ziółkowski, P.; Badur, J. Thermal utilization of meat and bone meals. Performance analysis in terms of drying process, pyrolysis and kinetics of volatiles combustion. Fuel 2019, 254, 115548. [CrossRef]

65. Batidzirai, B.; Mignot, A.P.R.; Schakel, W.B.; Junginger, H.M.; Faaij, A.P.C. Biomass torrefaction technology: Techno-economic status and future prospects. Energy 2013, 62, 196-214. [CrossRef]

66. Uslu, A.; Faaij, A.P.C.; Bergman, P.C.A. Pre-treatment technologies, and their effect on international bioenergy supply chain logistics. Techno-economic evaluation of torrefaction, fast pyrolysis and pelletisation. Energy 2008, 33, 1206-1223. [CrossRef]

67. Moliner, C.; Bosio, B.; Arato, E.; Ribes, A. Thermal and thermo-oxidative characterisation of rice straw for its use in energy valorisation processes. Fuel 2016, 180, 71-79. [CrossRef]

68. Uemura, Y.; Omar, W.; Othman, N.A.; Yusup, S.; Tsutsui, T. Torrefaction of oil palm EFB in the presence of oxygen. Fuel 2013, 103, 156-160. [CrossRef]

69. Eseltine, D.; Thanapal, S.S.; Annamalai, K.; Ranjan, D. Torrefaction of woody biomass (Juniper and Mesquite) using inert and non-inert gases. Fuel 2013, 113, 379-388. [CrossRef]

70. Uemura, Y.; Saadon, S.; Osman, N.; Mansor, N.; Tanoue, K.I. Torrefaction of oil palm kernel shell in the presence of oxygen and carbon dioxide. Fuel 2015, 144, 171-179. [CrossRef]

71. Chen, W.H.; Zhuang, Y.Q.; Liu, S.H.; Juang, T.T.; Tsai, C.M. Product characteristics from the torrefaction of oil palm fiber pellets in inert and oxidative atmospheres. Bioresour. Technol. 2016, 199, 367-374. [CrossRef] [PubMed]

72. Louwes, A.C.; Basile, L.; Yukananto, R.; Bhagwandas, J.C.; Bramer, E.A.; Brem, G. Torrefied biomass as feed for fast pyrolysis: An experimental study and chain analysis. Biomass Bioenergy 2017, 105, 116-126. [CrossRef]

73. Jagodzińska, K.; Zaini, I.N.; Svanberg, R.; Yang, W.; Jönsson, P.G. Pyrolysis of excavated waste from landfill mining: Characterisation of the process products. J. Clean. Prod. 2021, 279, 123541. [CrossRef] 
74. Kaczor, Z.; Buliński, Z.; Werle, S. Modelling approaches to waste biomass pyrolysis: A review. Renew. Energy 2020, 159, 427-443. [CrossRef]

75. Yaqoob, H.; Teoh, Y.H.; Sher, F.; Jamil, M.A.; Murtaza, D.; Al Qubeissi, M.; Ui Hassan, M.; Mujtaba, M.A. Current status and potential of tire pyrolysis oil production as an alternative fuel in developing countries. Sustainbility 2021, 13, 3214. [CrossRef]

76. Kwapinska, M.; Horvat, A.; Xue, G.; Kwapinski, W.; Rabou, L.P.L.M.; Dooley, S.; Leahy, J.J. The Effect of Equivalence Ratio on the Gasification of Torrefied and Un-Torrefied Biomass-Miscanthus $\times$ Giganteus. In Proceedings of the European Combustion Meeting 2015, Budapest, Hungary, 30 March-2 April 2015; pp. 1-7.

77. Xue, G.; Kwapinska, M.; Kwapinski, W.; Czajka, K.M.; Kennedy, J.; Leahy, J.J. Impact of torrefaction on properties of Miscanthus $\times$ giganteus relevant to gasification. Fuel 2014, 121, 189-197. [CrossRef]

78. Horvat, A.; Kwapinska, M.; Xue, G.; Rabou, L.P.L.M.; Pandey, D.S.; Kwapinski, W.; Leahy, J.J. Tars from Fluidized Bed Gasification of Raw and Torrefied Miscanthus $\times$ giganteus. Energy Fuels 2016, 30, 5693-5704. [CrossRef]

79. Ochnio, M.; Kluska, J.; Kardaś, D. Effects of biochar and ash outflow during updraft partial gasification on process parameters in a moving bed reactor. Chem. Pap. 2020, 74, 4047-4055. [CrossRef]

80. Huéscar Medina, C.; Sattar, H.; Phylaktou, H.N.; Andrews, G.E.; Gibbs, B.M. Explosion reactivity characterisation of pulverised torrefied spruce wood. J. Loss Prev. Process. Ind. 2015, 36, 287-295. [CrossRef]

81. Jian, J.; Lu, Z.; Yao, S.; Li, Y.; Liu, Z.; Lang, B.; Chen, Z. Effects of thermal conditions on char yield and char reactivity of woody biomass in stepwise pyrolysis. J. Anal. Appl. Pyrolysis 2019, 138, 211-217. [CrossRef]

82. Jackowski, M.; Niedzwiecki, L.; Lech, M.; Wnukowski, M.; Arora, A.; Tkaczuk-Serafin, M.; Baranowski, M.; Krochmalny, K.; Veetil, V.K.; Seruga, P.; et al. HTC of Wet Residues of the Brewing Process: Comprehensive Characterization of Produced Beer, Spent Grain and Valorized Residues. Energies 2020, 13, 2058. [CrossRef]

83. Jagodzińska, K.; Czerep, M.; Kudlek, E.; Wnukowski, M.; Pronobis, M.; Yang, W. Torrefaction of Agricultural Residues: Effect of Temperature and Residence Time on the Process Products Properties. J. Energy Resour. Technol. 2020, 142, 1-8. [CrossRef]

84. Magdziarz, A.; Gajek, M.; Nowak-Woźny, D.; Wilk, M. Mineral phase transformation of biomass ashes-Experimental and thermochemical calculations. Renew. Energy 2018, 128, 446-459. [CrossRef]

85. Margaritis, N.; Grammelis, P.; Karampinis, E.; Kanaveli, I.-P. Impact of Torrefaction on Vine Pruning's Fuel Characteristics. J. Energy Eng. 2020, 146, 04020006. [CrossRef]

86. Krochmalny, K.; Niedzwiecki, L.; Pelińska-Olko, E.; Wnukowski, M.; Czajka, K.; Tkaczuk-Serafin, M.; Pawlak-Kruczek, H. Determination of the marker for automation of torrefaction and slow pyrolysis processes-A case study of spherical wood particles. Renew. Energy 2020, 161, 350-360. [CrossRef]

87. Weber, K.; Heuer, S.; Quicker, P.; Li, T.; Løvås, T.; Scherer, V. An Alternative Approach for the Estimation of Biochar Yields. Energy Fuels 2018, 32, 9506-9512. [CrossRef]

88. Liaw, S.B.; Wu, H. A New Method for Direct Determination of Char Yield during Solid Fuel Pyrolysis in Drop-Tube Furnace at High Temperature and Its Comparison with Ash Tracer Method. Energy Fuels 2019, 33, 1509-1517. [CrossRef]

89. Poudel, J.; Karki, S.; Gu, J.H.; Lim, Y.; Oh, S.C. Effect of Co-Torrefaction on the Properties of Sewage Sludge and Waste Wood to Enhance Solid Fuel Qualities. J. Residuals Sci. Technol. 2017, 14, 23-36. [CrossRef]

90. Moscicki, K.J.; Niedzwiecki, L.; Owczarek, P.; Wnukowski, M. Commoditization of biomass: Dry torrefaction and pelletization-a review. J. Power Technol. 2014, 94, 233-249.

91. CEN (European Comitte for Standardisation). EN ISO 18122:2015 Solid Biofuels—Determination of Ash Content; Comite Europeen de Normalisation: Brussels, Belgium, 2015.

92. CEN (European Comitte for Standardisation). EN 15148:2009 Solid Biofuels—Determination of the Content of Volatile Matter; Comite Europeen de Normalisation: Brussels, Belgium, 2009.

93. CEN (European Comitte for Standardisation). EN ISO 16948:2015 Determination of Total Content of Carbon, Hydrogen and NitrogenInstrumental Methods; Comite Europeen de Normalisation: Brussels, Belgium, 2015.

94. Channiwala, S.A.; Parikh, P.P. A unified correlation for estimating HHV of solid, liquid and gaseous fuels. Fuel 2002, 81, 1051-1063. [CrossRef]

95. Brachi, P.; Miccio, F.; Miccio, M.; Ruoppolo, G. Isoconversional kinetic analysis of olive pomace decomposition under torrefaction operating conditions. Fuel Process. Technol. 2015, 130, 147-154. [CrossRef]

96. Qadi, N.; Kobayashi, M.; Takeno, K. Influence of torrefaction after densification on the fuel characteristics and the inherited gasification kinetics of Erianthus arundinaceus energy grass. Environ. Prog. Sustain. Energy 2019, 38, e13266. [CrossRef]

97. Szwaja, S.; Magdziarz, A.; Zajemska, M.; Poskart, A. A torrefaction of Sida hermaphrodita to improve fuel properties. Advanced analysis of torrefied products. Renew. Energy 2019, 141, 894-902. [CrossRef]

98. Szufa, S.; Adrian, Ł.; Piersa, P.; Romanowska-Duda, Z.; Marczak, M.; Ratajczyk-Szufa, J. Torrefaction Process of Millet and Cane Using Batch Reactor. In Renewable Energy Sources: Engineering, Technology, Innovation; Wróbel, M., Jewiarz, M., Szlęk, A., Eds.; Springer Nature Switzerland AG: Gewerbestr, Switzerland, 2020; pp. 371-379, ISBN 9783030138882.

99. Szufa, S.; Dzikuć, M.; Adrian, Ł.; Piersa, P.; Romanowska-Duda, Z.; Lewandowska, W.; Marcza, M.; Błaszczuk, A.; Piwowar, A. Torrefaction of oat straw to use as solid biofuel, an additive to organic fertilizers for agriculture purposes and activated carbon-TGA analysis, kinetics. E3S Web Conf. 2020, 154, 02004. [CrossRef]

100. Hejna, A.; Barczewski, M.; Skórczewska, K.; Szulc, J.; Chmielnicki, B.; Korol, J.; Formela, K. Sustainable upcycling of brewers' spent grain by thermo-mechanical treatment in twin-screw extruder. J. Clean. Prod. 2021, 285, 124839. [CrossRef] 
101. Reza, M.T.; Uddin, M.H.; Lynam, J.G.; Coronella, C.J. Engineered pellets from dry torrefied and HTC biochar blends. Biomass Bioenergy 2014, 63, 229-238. [CrossRef]

102. Pala, M.; Kantarli, I.C.; Buyukisik, H.B.; Yanik, J. Hydrothermal carbonization and torrefaction of grape pomace: A comparative evaluation. Bioresour. Technol. 2014, 161, 255-262. [CrossRef] [PubMed]

103. Bach, Q.V.; Tran, K.Q. Dry and Wet Torrefaction of Woody Biomass-A Comparative Studyon Combustion Kinetics. Energy Procedia 2015, 75, 150-155. [CrossRef]

104. Wilk, M.; Magdziarz, A. Hydrothermal carbonization, torrefaction and slow pyrolysis of Miscanthus giganteus. Energy 2017, 140, 1292-1304. [CrossRef]

105. Reza, M.T.; Lynam, J.G.; Uddin, M.H.; Coronella, C.J. Hydrothermal carbonization: Fate of inorganics. Biomass Bioenergy 2013, 49, 86-94. [CrossRef]

106. Kambo, H.S.; Dutta, A. Comparative evaluation of torrefaction and hydrothermal carbonization of lignocellulosic biomass for the production of solid biofuel. Energy Convers. Manag. 2015, 105, 746-755. [CrossRef]

107. Ohliger, A.; Forster, M.; Kneer, R. Torrefaction of beechwood: A parametric study including heat of reaction and grindability. Fuel 2013, 104, 607-613. [CrossRef]

108. van der Stelt, M.J.C.; Gerhauser, H.; Kiel, J.H.A.; Ptasinski, K.J. Biomass upgrading by torrefaction for the production of biofuels: A review. Biomass Bioenergy 2011, 35, 3748-3762. [CrossRef]

109. Kardaś, D.; Hercel, P.; Wardach-Święcicka, I.; Polesek-Karczewska, S. On the kinetic rate of biomass particle decompositionExperimental and numerical analysis. Energy 2021, 219, 119575. [CrossRef]

110. Luo, H.; Lu, Z.; Jensen, P.A.; Glarborg, P.; Lin, W.; Dam-Johansen, K.; Wu, H. Experimental and modelling study on the influence of wood type, density, water content, and temperature on wood devolatilization. Fuel 2020, 260, 116410. [CrossRef]

111. Brachi, P.; Miccio, F.; Miccio, M.; Ruoppolo, G. Torrefaction of Tomato Peel Residues in a Fluidized Bed of Inert Particles and a Fixed-Bed Reactor. Energy Fuels 2016, 30, 4858-4868. [CrossRef]

112. Trubetskaya, A.; Johnson, R.; Monaghan, R.F.D.; Ramos, A.S.; Brunsvik, A.; Wittgens, B.; Han, Y.; Pisano, I.; Leahy, J.J.; Budarin, V. Combined analytical strategies for chemical and physical characterization of tar from torrefaction of olive stone. Fuel 2021, 291, 120086. [CrossRef]

113. Brachi, P.; Chirone, R.; Miccio, M.; Ruoppolo, G. Fluidized bed torrefaction of biomass pellets: A comparison between oxidative and inert atmosphere. Powder Technol. 2019, 357, 97-107. [CrossRef]

114. Park, S.; Kim, S.J.; Oh, K.C.; Cho, L.H.; Kim, M.J.; Jeong, I.S.; Lee, C.G.; Kim, D.H. Characteristic analysis of torrefied pellets: Determining optimal torrefaction conditions for agri-byproduct. Energies 2020, 13, 423. [CrossRef]

115. Gucho, E.M.; Shahzad, K.; Bramer, E.A.; Akhtar, N.A.; Brem, G. Experimental study on dry torrefaction of beech wood and miscanthus. Energies 2015, 8, 3903-3923. [CrossRef]

116. Sh, L.; Lee, B.H.; Lee, Y.J.; Jeon, C.H. Comparing the physicochemical properties of upgraded biomass fuel by torrefaction and the ashless technique. Appl. Sci. 2019, 9, 5519. [CrossRef]

117. Järvinen, T.; Agar, D. Experimentally determined storage and handling properties of fuel pellets made from torrefied whole-tree pine chips, logging residues and beech stem wood. Fuel 2014, 129, 330-339. [CrossRef]

118. Acharjee, T.C.; Coronella, C.J.; Vasquez, V.R. Effect of thermal pretreatment on equilibrium moisture content of lignocellulosic biomass. Bioresour. Technol. 2011, 102, 4849-4854. [CrossRef]

119. Poletto, M.; Zattera, A.J. Materials produced from plant biomass: Part III: Degradation kinetics and hydrogen bonding in lignin Mater. Res. 2013, 16, 1065-1070. [CrossRef]

120. Jaworski, T.J.; Kajda-Szcześniak, M. Study on the similarity of the parameters of biomass and solid waste fuel combustion for the needs of thermal power engineering. Sustainbility 2020, 12, 7894. [CrossRef]

121. Ekielski, A.; Mishra, P.K.; Żelaziński, T. Assessing the Influence of Roasting Process Parameters on Mepiquat and Chlormequat Formation in Dark Barley Malts. Food Bioprocess. Technol. 2018, 11, 1177-1187. [CrossRef]

122. Cruz Ceballos, D.C.; Hawboldt, K.; Hellleur, R. Effect of production conditions on self-heating propensity of torrefied sawmill residues. Fuel 2015, 160, 227-237. [CrossRef]

123. Das, O.; Sarmah, A.K. The love-hate relationship of pyrolysis biochar and water: A perspective. Sci. Total Environ. 2015, 512-513, 682-685. [CrossRef]

124. Gray, M.; Johnson, M.G.; Dragila, M.I.; Kleber, M. Water uptake in biochars: The roles of porosity and hydrophobicity. Biomass Bioenergy 2014, 61, 196-205. [CrossRef]

125. Deborah, H.; Tobias, T.; Sindhu, N.B.; Nur, A.K.; Thomas, K.; Sarah, K.; Frank-Jürgen, M.; Matthias, R. Malt roasting quality control by mid-infrared spectroscopy. J. Brew. Distill. 2021, 10, 1-16. [CrossRef]

126. Daniels, R. Designing Great Beers: The Ultimate Guide to Brewing Classic Beer Styles; Brewers Publications: Boulder, CO, USA, 1998; ISBN 0937381500.

127. Mainardis, M.; Flaibani, S.; Mazzolini, F.; Peressotti, A.; Goi, D. Techno-economic analysis of anaerobic digestion implementation in small Italian breweries and evaluation of biochar and granular activated carbon addition effect on methane yield. J. Environ. Chem. Eng. 2019, 7, 103184. [CrossRef]

128. Szwaja, S.; Kovacs, V.B.; Bereczky, A.; Penninger, A. Sewage sludge producer gas enriched with methane as a fuel to a spark ignited engine. Fuel Process. Technol. 2013, 110, 160-166. [CrossRef]

129. Heller, M. Food Products Environmental Footprint Literature Summary: Beer; The Oregon Sustainability Board: Salem, OR, USA, 2017. 